\title{
Articles
}

\section{Free Movement of Electricity and the Revival of System Stability Justifications}

\author{
By Max Salomon Jansson *
}

\begin{abstract}
EU Member States have in recent years designed national schemes to support the development of renewable energy. For example, in systems of feed-in-tariffs the states guarantee for a given period of time plants generating electricity from renewable resources the market price plus a premium. These feed-in-tariffs have normally only been awarded to electricity generated in-state. The preference given to in-state industry has been challenged in court as contradicting the principle non-discrimination on the European internal market. The decision by national legislatures to limit the availability of feed-intariffs to electricity generated in-state, however, has-to the surprise of many-been found justifiable by the European Court of Justice. This Article illustrates how the objective to ensure system stability has emerged as the strongest ground of justification in the context of cross-border electricity trade and how similar arguments have actually been used previously in the context of the health care service sector. While the reasoning of the court is defendable, the court could have developed an even more nuanced and informative position if it had taken notice of additional aspects that have popped up in the U.S. debate on similar questions.
\end{abstract}

*PhD candidate at Vrije Universiteit Brussel and University of Turku. 


\section{A. Introduction}

For years, the European Union has already developed a policy to promote energy from renewable resources. ${ }^{1} \mathrm{~A}$ key objective with this strategy is to reduce the dependency on fossil fuel, in part because of the effects their greenhouse gas (GHG) emissions is having on the global climate. These efforts can only be expected to intensify following the international deal struck at the 21st annual Conference of the Parties hosted by the United Nations Framework Convention on Climate Change (COP21). ${ }^{2}$

The responsibility to implement the strategy lies with the EU's Member States. They have indeed put in place schemes that support renewables but have also commonly included provisions that limit the access of this support to domestically produced energy. Such provisions create fragmentation on the internal energy market and run counter to the stated objective of completing the energy union. ${ }^{3}$ Importantly, the compatibility of the schemes with the provisions on free movement of goods in Articles 34-36 of the Treaty on the Functioning of the European Union (TFEU) has already been challenged at least three times.

In PreussenElektra, ${ }^{4}$ the Court of Justice of the European Union (CJEU) was presented with a case concerning the German system of feed-in-tariffs (FITs). According to national law, an energy supplier is required to buy all renewable energy produced in their region of establishment at a fixed price. A supplier could receive a partial reimbursement in case the purchased renewable energy exceeded five percent of the total supply of that supplier. PreussenElektra claimed to have an interest in buying more affordable renewable energy from abroad and objected to being obliged to buy a large share of domestic energy on the grounds that this reduced its importing capacity.

In the years after PreussenElektra, the EU has formed a concrete strategy to increase the share of renewable energy to 20 per cent of its energy consumption in 2020. In order to achieve this target, each Member State has been assigned a national target and shall, in

\footnotetext{
${ }^{1}$ Commission Communication, Energy 2020: A strategy for competitive, sustainable and secure energy, COM (2010) 639 final; Commission Communication, Energy Roadmap 2050, COM (2011) 885 final; Commission Communication, A policy framework for climate and energy in the period from 2020 to 2030, COM (2014) 15 final.

${ }^{2}$ COP21, Adoption of the Paris Agreement, Dec. 12, 2015, UNFCCC/CP/2015/L.9.

${ }^{3}$ Commission Communication, A Framework Strategy for a Resilient Energy Union with a Forward-Looking Climate Change Policy, COM (2015) 80 final.

${ }^{4}$ Case C-379/98, PreussenElektra AG v. Schhleswag AG, 2001 E.C.R. I-2099 (hereinafter PreussenElektra).
} 
accordance with the Renewable Energy Directive (RED), ${ }^{5}$ establish support schemes promoting the growth of the renewable energy sector. Article 3 and recital 25 of RED provide that EU Member States may have national support schemes for renewables and may decide whether and to what extent these schemes are open for out-of-state producers. This does not automatically mean that the schemes and the directive would comply with primary law.

Recently, the principles of PreussenElektra were tested again before the CJEU. Essent Belgium $^{6}$ concerned the Belgium's Renewable Portfolio Standard (RPS). The implementation on an RPS means that Belgian suppliers of energy all have to buy a number of renewable energy certificates (RECs) from producers of renewable energy in order to fill a quota that is dependent on total supply volumes. Although the option is in theory not fully excluded by the national law, Belgian authorities have never accepted foreign RECs, nor awarded RECs to imports.

Ålands Vindkraft was a similar case to Essent Belgium. It related to the Swedish system, wherein suppliers also have to buy green certificates. The system was not, however, contested by any Swedish energy supplier. The plaintiff was instead Ålands Vindkraft, a Finnish wind power company that asked the authorities of Sweden to award Swedish RECs for the power it supplied the Swedish network. ${ }^{7}$

In all three cases, the CJEU upheld the de jure discriminatory provisions of the national schemes. At a first glance, the CJEU approach may seem puzzling given both the rarity of cases in which de jure discrimination has been deemed justifiable and in light of the fact that encouraging support to renewables in other EU Member States could be expected to have positive effects for the environment. It may also be noted that American scholars

\footnotetext{
${ }^{5}$ Directive 2009/28/EC of the European Parliament and of the Council of 23 April 2009 on the promotion of the use of energy from renewable sources and amending and subsequently repealing Directives 2001/77/EC and 2003/30/EC, O.J. L 140/16, June 5, 2009 (hereinafter RED).

${ }^{6}$ Joined Cases C-204/12 to C-208/12 Essent Belgium NV v Vlaamse Reguleringsinstantie voor de Elektriciteits- en Gasmarkt, judgment of Sept. 11, 2014 (hereinafter Essent Belgium).

7 Case C-573/12, Ålands Vindkraft AB v. Energimyndigheten, Judgment of July 1, 2014 (hereinafter Ålands Vindkraft).
} 
have determined that in-state requirements breach their Dormant Commerce Clause. ${ }^{8}$ Furthermore, when these laws have been challenged in court, American states repealed the de jure discriminatory provision. ${ }^{9}$

The objectives of this article are to explore different theories concerning the justification of de jure discrimination in free movement law and provide an explanation as to why the decisions by the CJEU may have been both politically and legally reasonable. The systematization of arguments presented herein will offer tools to tackle future cases of de jure discrimination.

\section{B. Free Movement Law and the Energy Sector}

Article 34 of the TFEU prohibits quotas and measures having equivalent effect. In accordance with CJEU case law, measures hindering market access are prima facie prohibited. Despite the ambiguity of this test, it is clear that de jure and de facto discrimination are included. ${ }^{10}$ Direct or de jure discrimination has never been defined by

\footnotetext{
${ }^{8}$ Trevor D. Stiles, Renewable Resources and the Dormant Commerce Clause, 4 ENVIR. \& ENERGY L. \& POL'Y J. 34, 64 (2009); Carolyn Elefant and Edward A. Holt, The Commerce Clause and Implications for State Renewable Portfolio Standard Programs, CleanEnergy States Alliance: State RPS Policy Report, March 2011, 4-15; Kirsten H. Engel, The Dormant Commerce Clause Threat to Market-Based Environmental Regulation: The Case of Electricity Deregulation, 26 Ecology L. Q. 243, 272-74 (1999); Steven Ferrey, Sustainable Energy, Environmental Policy, and States' Rights: Discerning the Energy Future Through the Eye of the Dormant Commerce Clause, 12 N.Y.U. ENVIR. L. J. 507, 583 (2004); Nathan Endrud, State Renewable Portfolio Standards: Their Continued Validity and Relevance in Light of the Dormant Commerce Clause, the Supremacy Clause, and Possible Federal Legislation, 45 HARV. J. Legislation 259, 270 (2008); Patrick R. Jacobi, Note, Renewable Portfolio Standard Generator Applicability Requirements: How States Can Stop Worrying and Learn to Love the Dormant Commerce Clause, 30 VT. L. REV. 1079, 1111-112 (2006).

${ }^{9}$ TransCanada Power Marketing v. lan Bowles et al., No. 4:10-cv-40070-FDS (complaint April 16, 2010) (D. Mass.) (in-state requirement repealed, case settled); State, ex rel. Missouri Energy Development Ass'n v. Public Service Com'n, 386 S.W.3d 165 (Mo. App. Ct. W.D. 2012) (in-state requirement repealed, case dropped); Nichols and FuelCell Energy, Inc., v. Markell, et al, No. 1:12-cv-00777 (D. Del.) (in-state requirement repealed, case dropped). See also In the Matter of the Application of Champaign Wind, LLC, for a Certificate to Construct a Wind-Powered Electric Generating Facility in Champaign County, Ohio, Case No. 13-1874 (Ohio 2014); and In the Matter of the Commission's Review of its Rules for the Alternative Energy Portfolio Standard Contained in Chapter 4901:1-40 of the Ohio Code, Case No. 13-652-EL-ORD (repealing the in-state requirement).

10 On the general scope of prima facie prohibited measures, see Max S. Jansson and Harri Kalimo, De Minimis Meets "Market Access": Transformations in the Substance-and the Syntax-of EU Free Movement Law?, 51 COMmon MKT. L. Rev. 523 (2014).
} 
the CJEU ${ }^{11}$ The definition of this term should capture discrimination on the grounds of not only nationality, but also any other direct reference to geographic origin. It would in other words capture measures that differentiate on the basis of the nationality of the producer, the destination of the good as well as the place of production. ${ }^{12}$ In addition, criteria on transport distance can be regarded as a comparable form of discrimination in that the link is direct to geographical origin.

It should be noted that different treatment of like products on the basis of geographical origin is not automatically a case of discrimination. To rise to the level of discrimination, the out-of-state origin must also be treated less favorable. Not accepting foreign power when granting feed-in-tariffs or when granting renewable energy credits would clearly fulfill that criterion. ${ }^{13}$

Prima facie prohibited measures may rely on grounds of justification such as the protection of public health or the environment. In addition, any justification must be proportional in light of its legitimate objective. At this point, it is sufficient to note that measures are generally deemed proportional so long as they are suitable and necessary to achieve the legitimate objective. ${ }^{14}$ The requirement of necessity essentially means that there should exist no less restrictive or discriminatory alternative that would serve the legitimate noneconomic objective equally well. ${ }^{15}$

De jure discrimination rarely survives the proportional review. The CJEU has often rather swiftly rejected the justifiability of de jure discriminatory measures by either stating that

\footnotetext{
${ }^{11}$ Case C-73/08, Nicolas Bressol and Others and Céline Chaverot and Others v. Gouvernement de la Communauté française, 2010 E.C.R. I-2735, para. 43 (opinion of AG Sharpston).

${ }^{12}$ Outside the context of free movement of goods, it would also cover differentiation on the basis of, for example, residence. On differentiation on the basis of where a health service was obtained, see also Case C-120/95, Nicolas Decker v. Caisse de maladie des employés privés, 1998 E.C.R. I-1831, paras. 34-36 (hereinafter Decker).

${ }^{13}$ Renewable energy credits (RECS) in different jurisdictions may represent very different attributes and are therefore not like products. There could therefore be an obligation to grant foreign power RECs while there would be no obligation to accept foreign RECs.

14 Joined cases 279/84, 280/84, 285/84 and 286/84 Walter Rau Lebensmittelwerke and others v. Commission, 1987 E.C.R .1069, para. 34.

${ }^{15}$ Case C-131/93, Commission v. Germany, 1994 E.C.R. I-3303, para. 18.
} 
they are not necessary or that they form arbitrary discrimination. ${ }^{16}$ In many cases, a measure will be less discriminatory by simply removing the de jure discriminatory element, without endangering the objective to, for example, protect the environment. An out-ofstate product with environmentally friendly characteristics or produced with environmentally sustainable process and production methods (PPMs) will presumably benefit the environment much in the same manner as any identical in-state competing product. A situation in which there is no acceptable alternative for a de jure discriminatory measure would appear to occur only when there is some reason, apart from the origin of the product, to treat products differently. In sum, there needs to be a rational relation between the de jure discriminatory element of the measure and the objective of environmental protection. ${ }^{17}$ Rarely is there one, and therefore most measures will not survive any proportionality review.

\section{Preliminary Questions}

Before taking on theories concerning the justification of de jure discrimination, one must address a couple of preliminary considerations. First, it should be pointed out that apart from primary law, including the rules on free movement, the EU has produced a large body of secondary law covering many sectors. Some secondary laws fully harmonize rules on environmental protection. This means that Member States may not adopt national rules that are stricter than the common EU rules. The CJEU has outlined that when a matter has been fully harmonized in secondary law, cases should be solved on the basis of those provisions and not primary law. ${ }^{18}$

Article 3 RED grants each Member state the right to design their national renewable support schemes and this decision on the non-harmonization of schemes does not represent harmonization in itself. ${ }^{19}$ In recent energy cases the CJEU stated that because the RED did not represent full harmonization of support schemes for renewables, Member States could still rely on grounds of justification in defending discrimination that prima

\footnotetext{
16 Case 434/85, Allen and Hanburys Ltd v. Generics (UK) Ltd [1988] E.C.R. 1245, paras. 14-22. See also Joined cases C-321/94, C-322/94, C-323/94 and C-324/94 Criminal proceedings against Jacques Pistre, Michèle Barthes, Yves Milhau and Didier Oberti, 1997 E.C.R. I-2343.

17 Boris I. BitTKer, Bittker on the Regulation of INTERSTATE AND Foreign COMmerCe 6-46-47 (1999). Bittker discusses similar issues in relation to US constitutional law.

${ }^{18}$ Case C-309/02 Radlberger Getränkegesellschaft mbH \& Co. and S. Spitz KG v Land Baden-Württemberg, 2004 E.C.R. I-11763, para. 53; Ålands Vindkraft, supra note 7, para. 57.

${ }^{19}$ Armin Steinbach and Robert Brückmann, Renewable Energy and the Free Movement of Goods, 27 J. ENVIR. L. 1, 7-8 (2015).
} 
facie is contra the TFEU. ${ }^{20}$ Although this conclusion appears justified, it is in one sense incomplete. Namely, even if the directive had been deemed to have fully harmonized the matter, the directive itself, and by extension the measures adopted in accordance therewith, could still have breached primary law.

Secondly, there has been the question regarding the scope of legitimate objectives that may be referred to as grounds of justification in the case of de jure discriminatory measures. Prima facie prohibited measures can be justified with reference to the grounds listed in Article 36, including the protection of public health. The CJEU has, however, also developed mandatory requirements, ${ }^{21}$ including the protection of the environment. ${ }^{22}$ While the mandatory requirements traditionally could only justify measures that were not de jure discriminatory, that appears to have changed with more recent case law; ${ }^{23}$ yet the CJEU has not, to date, explicitly overturned the traditional doctrine. According to Bjørnebye ${ }^{24}$, the CJEU even went so far in Essent Belgium as to avoid declaring the in-state requirement as de jure discriminatory, even if it obviously was.

There are two ways to approach the matter: First, environmental protection can be read as part of the objective to protect public health. Hence, it would fall under the scope of Article 36 and could thus justify de jure discrimination. The grounds of justification, however, are exemptions and should be interpreted narrowly. ${ }^{25}$ Therefore, it has been argued that the ground of justification stipulated in Article 36 TFEU comes into play only when there is a direct health risk. ${ }^{26}$ This might not be the case when the effects only

\footnotetext{
20 Ålands Vindkraft, supra note 7, para. 63. See also Essent Belgium, supra note 6, para. 97.

${ }^{21}$ Case 120/78, Rewe-Zentral AG v. Bundesmonopolverwaltung für Branntwein (Cassis de Dijon), 1979 E.C.R. 649, paras. 8-10.

22 Case 240/83, Procureur de la Republique v. Association de defense des bruleurs d'huiles usages, 1985 E.C.R. 531, para. 15 (hereinafter ADBHU); Case 302/86, Commission v. Denmark (Danish Bottles), 1988 E.C.R. 4607, paras. 6-9.

${ }^{23}$ PreussenElektra, supra note 4, paras. 72-77. See also ADBHU, supra note 22, para 15; Essent Belgium, supra note 6, paras. 89-95.

${ }^{24}$ Henrik Bjørnebye, Joined Cases C-204/12 to C-208/12 Essent Belgium, 13 OIL, GAS \& ENeRGY L. INTelLigenCE 6 (2015).

${ }^{25}$ Case 46/76, W.J.G. Bauhuis v. The Netherlands State, 1977 E.C.R. 5, para. 12; Case 113/80, Commission v Ireland, 1981 E.C.R. 1625, para. 7.

${ }^{26}$ Ludwig Krämer, Environmental Protection and Art. 30 EEC Treaty, 30 COMmON MKT. L. REV. 111, 118 (1993); ANDREAS R. ZIEGLER, TRAdE AND ENVIRONMENTAL LAW IN THE EUROPEAN COMMUNITY 72 (1996).
} 
manifest in the long term; ${ }^{27}$ Yet, no bias against slowly accumulating but severe effects should exist. In general, the severity of environmental effects would justify a broader understanding of health as a ground of justification. ${ }^{28}$ Thus, many long-term effects should be accepted. ${ }^{29}$ The same is true for unlikely but severe effects. Still, the case law of the CJEU is not entirely clear on this point. Nevertheless, the CJEU has hinted that the protection of biodiversity ${ }^{30}$ as well as the promotion of renewable energy ${ }^{31}$ are of such importance to the environment that they may each be considered as promoting the protection of health.

The above approach of reading environment into the concept of public health in Article 36 would, of course, leave unsettled the faith of other mandatory requirements in relation to de jure discrimination. Alternatively, as advocated by several scholars, ${ }^{32}$ the traditional line between Article 36 grounds of justification and environmental protection or even mandatory requirements in general would be erased and could all be used for justification of de jure discrimination.

The fact that a measure, such as a scheme promoting renewables, provides an economic advantage for the domestic industry will not bar justifications as long as the reasons for the FIT were primarily environmental. ${ }^{33}$ This leaves us with the decisive question: How does an in-state requirement actually contribute to environmental protection? ${ }^{34}$

\footnotetext{
${ }^{27}$ For a critical review of stretching the protection of health to long term effects see JUKKA SNELL, GOODS AND SERVICES IN EC LAW: A StUdy on the Relationship BetWEen the Freedoms 180 (2002).

${ }^{28}$ HENRIK BJøRNEBYE, INVESTING IN EU ENERGY SECURITY-EXPLORING THE REGULATORY APPROACH TO TOMORROW'S ELECTRICITY PRODUCTION 109-10 (2010).

${ }^{29}$ PreussenElektra, supra note 4, para. 232 (opinion of AG Jacobs).

30 Case C-67/97, Criminal Proceedings against Ditlev Bluhme, 1998 E.C.R. I-8033, para. 33; Case C-100/08, Commission v. Belgium, 2009 E.C.R. I-140, para. 93.

${ }^{31}$ PreussenElektra, supra note 4, paras. 229-38 (opinion of AG Jacobs); PreussenElektra, supra note 4, para. 75.

32 Steinbach \& Brückmann, supra note 20, 8-12; Marek Szydło, How to reconcile national support for renewable energy with internal market obligations? The task for the EU legislature after Ålands Vindkraft and Essent, 52 Common Mкт. L. Rev. 489, 500-03 (2015); Sirja-Leena Penttinen, Ålands Vindkraft AB v Energimyndigheten-The Free Movement Law Perspective, 13 OIL, GAS \& ENERgy L. INTELLIGeNCE 16-20 (2015).

${ }^{33}$ Case 72/83, Campus Oil Limited and Others v Minister for Industry and Energy and Others, 1984 E.C.R. 2727, paras. $23-25,35-36$

${ }^{34}$ Szydło, supra note $32,504-05$. He indicates that there may be no clear and satisfactory answer.
} 


\section{The Proximity Principle}

\section{The Cases of Waste: Transport Risks}

The case of Walloon Waste ${ }^{35}$ concerned a universal waste import prohibition implemented by the Walloon government in Belgium. As it regards hazardous waste, this measure was in breach of the rules on notification procedures laid out in a community waste directive. ${ }^{36}$ In contrast, trade in non-hazardous waste was not within the scope of any directive. Hence, the CJEU applied the TFEU provisions on free movement of goods and concluded that the ban on the importation of foreign waste was not discriminatory. This ruling could only be understood as representing the view that domestic and imported waste were not likeproducts. The CJEU relied on a Treaty article, now 191(2) TFEU, which stipulates that environmental damage shall, as a matter of priority, be remedied at its source. ${ }^{37}$ To give further weight to this argument, the EUCJ referred to the principles of self-sufficiency and proximity established by the Basel Convention on hazardous wastes, ${ }^{38}$ to which the EU has been a signatory since the Convention's drafting in 1989. All in all, the court applied a principle of proximity in the context of waste transport. ${ }^{39}$ Notably, this was opposite to the approach taken by the United States Supreme Court. ${ }^{40}$

The CJEU judgment in Walloon Waste received harsh criticism from scholars who argued that the court should have followed existing tests of competition and substitutability in

\footnotetext{
${ }^{35}$ Case C-2/90, Commission v. Belgium, 1992 E.C.R. I-4431, paras. 34-37 (hereinafter Walloon Waste).

${ }^{36}$ Walloon Waste, supra note 35, paras. 20-21; Council Directive 84/631/EEC of 6 December 1984 on the supervision and control within the European Community of the transfrontier shipment of hazardous waste, O.J. L 326, 31 (Dec. 31, 1984).

${ }^{37}$ Walloon Waste, supra note 35, para. 34.

38 UNEP, Basel Convention on the control of transboundary movements of hazardous wastes and their disposal, 22 March 1989. See especially art. 4.

${ }^{39}$ Before Walloon Waste, the EUCJ had appeared critical of the proximity principle. See Case $172 / 82$, Syndicat national des fabricants raffineurs d'huile de graissage and others $v$ Groupement d'intérêt économique "InterHuiles", 1983 E.C.R. 555, para. 14.

40 Philadelphia v. New Jersey 437 U.S. 617, 622-26 (1978); Fort Gratiot Sanitary Landfill v. Michigan Dep't of Natural Resources (91-636), 504 U.S. 353 (1992); Chemical Waste Management, Inc. v. Hunt, 504 U.S. 334 (1992).
} 
determining likeness. ${ }^{41}$ That being said, the recognition of the principle of proximity is in itself significant. Even if the court had adhered to a more restrictive likeness test, this principle could still come into play in law of justification. The attributes of proximity could create the necessary rational relationship between de jure discrimination and the objective.

In the particular context of hazardous waste, the principle of proximity reflects a concern with regards to the risks of transportation. In this respect the reference to the Basel Convention was perhaps puzzling, as it specifically concerns hazardous wastes and the CJEU was, in fact, applying the TFEU provisions only to the ban on import of non-hazardous wastes. Arguably the transport of non-hazardous waste-for example, old solar panelswill pose less of an environmental risk, whereas the transport of radioactive nuclear waste inarguable represents a much greater risk. Indeed, the EU has adopted a directive to restrict the cross-border transport of nuclear waste. ${ }^{42}$

Risk, in general, is a matter of degree of harm and probability. The transport of oil and fuels will increase environmental risks, as would almost any transport to some degree. The Basel Convention and the Nuclear Waste Directive both support the conclusion that de jure restrictions are justified only when the risk is exceptionally severe. A broader application of the proximity principle creates a crack in the fundamentals of trade law. More minor transportation must instead be monitored primarily through laws on accident compensation liability.

\section{Transport Distance and Pollution}

In much the same way as transport accident risks increase with distance, so may risk of pollution. This is true for the transport of many goods, including but not limited to feedstock and fuel. Thus, potential pollution has constituted one reason for the increased interest in consumption of primarily local food. Electricity is, to some degree, a special case because it is not transported by road, air and sea, but rather along transmission lines. Transmissions over long distances, however, could result in the loss of energy along these power lines. In addition, building power lines may also have detrimental environmental impacts, in particular if sited through environmentally sensitive nature land.

\footnotetext{
41 Damien Geradin, Trade and the Enviornment-A Comparative Study of EC and US LaW 19-22 (1997); Peter Von Wilmowsky, Waste Disposal in the Internal Market: The State of Play After the ECJ's Ruling on the Walloon Import Ban, 30 Сомmon Mкт. L. Rev. 541, 547 (1993); Nicolas Bernard, Discrimination and Free Movement in EC Law, 45 INT'L \& COMP. L. Q. 82, 94 (1996). See also PreussenElektra, supra note 4, para. 225 (opinion of AG Jacobs).

42 Council Directive 2006/117/Euratom of 20 November 2006 on the supervision and control of shipments of radioactive waste and spent fuel, O.J. L 337, 21 (Dec. 5, 2006).
} 
In his opinion in PreussenElektra, Advocate General Jacobs appeared to argue that the principle of proximity could come into play. He, however, would have left it to the national court to evaluate whether or not electricity was lost along the power lines to such an extent that discrimination would be necessary and justified. ${ }^{43}$ In contrast, in his Essent Belgium opinion, Advocate General Bot rejected the idea of giving relevance to the principle of proximity in the field of renewable energy by arguing that the Belgian measure could not be justified because electricity from domestic renewables is no more environmental friendly than the same from other Member States. ${ }^{44}$

The long distance transport of any good is bound to cause more pollution and have a more severe environmental impact than local trade. De jure discrimination justified based upon transport or transmission distances would nullify the whole idea of an internal market. Although the environmental effects of transport cannot be denied in most cases, national origin is still an inappropriate proxy for determining the potential level of transport pollution. ${ }^{45}$ For example, the distance for imports could, in some cases, be shorter than the distance for in-state transport.

An alternative to de jure discrimination would be restrictions of severity in relation to the exact distance, instead of the state of origin. The distance would, in other words, serve as a proxy for pollution. Two potential problems could still remain: First, if states may only justify restrictions with reference to the negative environmental effects that reach their own territory, then distance could be a poor proxy because covering a one kilometer transport distance far away from the state-border would arguably have less of an environmental impact to the importing state than covering the same transport distance closer to the border. Secondly, even if we disregard this concern, it would appear arbitrary to only focus on pollution from transport when similar, if not identical, pollution may occur at other stages of the process from production to end-of-life treatment. Hence, regardless of the proportionality test applied, distance as the sole proxy would seem difficult to justify. Instead, states should include it in a life-cycle analysis.

\footnotetext{
${ }^{43}$ PreussenElektra, supra note 4, paras. 235-37 (opinion of AG Jacobs).

${ }^{44}$ Essent Belgium, supra note 6, para. 104 (opinion of Advocate General Bot).

${ }^{45}$ Eleanor Stein, Regional Initiatives to Reduce Greenhouse Gas Emissions, in GLobal CLIMATE CHANGE AND US LAW 271, 291 (Michael Gerrard \& Jody Freeman eds., 2014).
} 


\section{E. Prioritizing Local Environment}

States often implement programs to improve the sustainability of in-state PPMs in order to gain local environmental benefits. If such programs are open to out-of-state operators, however, some of the environmental benefits will leak out-of-state.

With regard to schemes promoting renewable energy, even if out-of-state projects would be eligible for such schemes, the benefits of lower GHGs would not leak out-of-state because of their transcendent nature. In addition, the state's implementing support schemes would also forego some of the negative environmental effects associated with renewable energy projects if most of them are carried out out-of-state. With other states reaping the benefits of the program, however, the risk would be significantly greater that the state adopting the measure would not to the same extent be able to phase out its domestic fossil fuel or nuclear energy plants. This could also have negative local environmental impacts such as many forms of air, water and soil pollution. If fossil fuel plants and other factories with high pollution are not replaced domestically, but are instead replaced in other states, then the environmental benefits in the state adopting the measure may be very indirect and small beyond GHG mitigation. ${ }^{46}$ From the perspective of adopting state the program might therefore fail to improve local environmental conditions to the targeted extent.

Introducing a de jure discriminatory barrier to the program of promoting renewables would hinder the economic and environmental benefits from leaking out-of-state. The structure of law of justification may lend some support for accepting the preference for instate environment as justification. According to one unconfirmed theory, states may only be justified in protecting their own environment and global effects to the extent that these effects reach their own territory. ${ }^{47}$ Consequently, there is some appeal to the symmetry of then allowing states to give preference to their own respective environments. At no point, however, did the Walloon Waste court suggest that the reason for upholding the law was in any way related to any right to prioritize local environments over foreign ones. Both the importation of waste and programs promoting sustainable PPMs naturally have their own particularities. Yet, the principle that seems to emerge represents a rejection of prioritization of the domestic environment.

\footnotetext{
${ }^{46}$ Ferrey, supra note 8, at 590; Endrud, supra note 8, at 263-64; Anne Havemann, Surviving the Commerce Clause: How Maryland Can Square Its Renewable Energy Laws with the Federal Constitution, 71 MARYLAND L. REV. 848, 884 (2005).

${ }^{47}$ Case C-5/94, The Queen v. Ministry of Agriculture, Fischeries and Food, ex parte: Hedley Lomas (Ireland) Ltd., 1996 E.C.R. 2553, para. 20; Case 8/74, Procureur du Roi v. Gustave Dassonville, 1974 E.C.R. 837, para. 5 (opinion of AG Trabucchi). See also ZIEGLER, supra note 26, 84-90; Case C-169/89, Criminal proceedings against Gourmetterie Van den Burg, 1990 E.C.R. I-2143, para. 12.
} 


\section{F. Pollution Accumulation and Concentration}

The American waste cases as decided by the Supreme Court of the United States have revealed other potential arguments for de jure discrimination beyond the principle of proximity. In his dissenting opinion in Philadelphia $v$. New Jersey, Justice Rehnquist presented the view that the risk from waste slowly piling up may be a serious enough risk to justify facial discrimination. ${ }^{48}$ This was linked to New Jersey's concerns regarding the limited availability of landfills. In theory, waste companies, in a free and competitive market, will ship their waste to areas with cheap land, also benefiting from economies of scale. Thus, some states could be expected to be the destination of a large portion of waste. The majority in Philadelphia rejected the view of Justice Rehnquist. In contrast, the CJEU in Walloon Waste did refer to the risks of accumulation of waste as a valid ground of justification. ${ }^{49}$ The case was, however, primarily solved on different grounds. The few lines on accumulation of waste in the Walloon Waste case could still have significance and even be relevant for the energy sector.

Waste and pollution from energy plants share the common feature that their value is generally negative. Accumulation of pollution creates an environmental effect that can be more harmful for both the European and global environments than if the same amount of pollution was distributed more evenly throughout Europe. In other words, the marginal effects of the pollution from energy plants may become more severe with a higher degree of concentration. Consequently, states may be justified in protecting themselves against this form of pollution accumulation and concentration.

How could the pollution concentration risk then materialize? Member States promote clean production methods, including renewables. A small number of states may adopt this strategy despite poor access to renewable resources. If they are barred from limiting their support to electricity generated in-state, there would be, in theory, a risk that the scheme would primarily benefit out-of-state projects with competitive advantages. The consequence of this may be that the states' own fossil fuel plants and/or nuclear power plants may not be replaced by in-state renewable energy plants. For GHG emissions, the location of the replaced plants is of course irrelevant from an environmental perspective. Yet, the local pollution of a coal plant or risks of nuclear power plants would remain high in a few states while other states form the heart of the transition toward renewables. Pollution concentration concerns have led some to note that in-state requirements could

\footnotetext{
${ }^{48}$ Philadelphia v. New Jersey 437 U.S. 617, 632-33 (1978).

${ }^{49}$ Walloon Waste, supra note 35, paras. 30-32.
} 
potentially be justified..$^{50}$ Uncertainty, however, remains as to whether these concerns are valid under EU primary law.

The Ålands Vindkraft case concerned the decision of Sweden to reject RECs for power imported from the Aland Islands, which form an autonomous territory of Finland. Here, the court noted that Sweden had already achieved a relatively large share of renewables. ${ }^{51}$ In fact the same is true for Finland and the islands. There was thus no risk of unusual concentration of fossil fuels or nuclear power and the theory was not put to test.

It should be pointed out that the accumulation of pollution is not fully identical to the accumulation of waste. Even with strict recycling standards some domestic waste will always accumulate, which means imports would need to be permitted in order to avoid discrimination and the importing state would thus have little control over the amounts of waste imported. In the case of pollution or risks of non-renewable energy plants the accumulation originates from in-state PPMs. Thus, even if the state could not manage to divert its funds to develop a renewable energy industry of desired scale in-state, it would be in a better position to tackle the problem of pollution concentration.

The strength of the pollution concentration argument depends upon the analysis of alternatives, such as stricter pollution standards for fossil fuels, bearing in mind the restraints that arise from security of supply concerns. Without the facts of a "real," nonhypothetical case, it is only possible to conclude that the accumulation of pollution argument has some strength, but that it would, at most, remain accessible for states with exceptionally poor access to renewables. Such states may or may not exist within the EU.

\section{G. Difficulties of Verification}

In PreussenElektra, the CJEU analyzed the proportionality of the de jure discriminatory FIT and decided that, in the current state of EU energy law, discrimination may be justifiable. The court took the view that it would be too difficult for national administrations to confirm whether or not the energy provided for by a foreign producer had been produced from renewable sources. ${ }^{52}$ This would suggest that, in cases where the sustainability of the PPMs are impossible to verify for imports, de jure discrimination would be justified.

\footnotetext{
${ }^{50}$ Angus Johnston et al., The Proposed New EU Renewables Directive: Interpretation, Problems and Prospects, 17 EURo. ENergy \& ENVIR. L. ReV. 126, 136 (2008); ANGUS Johnston \& GUY BLock, EU ENERGY LAW 348 (2012).

51 Ålands Vindkraft, supra note 7, para. 102.

${ }^{52}$ PreussenElektra, supra note 4 , paras. $78-80$.
} 
However, the case was decided in the late 90 s and the court noted the possibility that the situation could change with legislative reforms. ${ }^{53}$

The conclusion in PreussenElektra seemed to contradict the ruling in Outokumpu, ${ }^{54}$ decided only a couple of years prior. The Outokumpu case did not concern the free movement of goods, but rather the internal taxation of energy in Finland. A lower tax rate applied to domestic energy if the energy had been produced from renewable sources. In contrast, all foreign energy was taxed with a flat rate that lay somewhere in between the rate for domestic renewable energy and that for non-renewable energy. This tax structure created a disadvantage for foreign renewable energy that the Finnish government tried to justify on the ground that it was too difficult to validate that the imported energy actually was from renewable sources. ${ }^{55}$ The court declined to accept this argument, stating that the practical difficulty of validating the origin of the energy did not form a ground of justification. ${ }^{56}$ The measure was disproportionate because the Finnish authorities did not even give importers the possibility to present documentation proving that the energy was from renewable sources. ${ }^{57}$ What the case clearly confirmed was that states would at least need to permit importers to present proof of origin and PPMs. Read together with PreussenElektra, these cases left it very uncertain as to whether verification difficulties could justify de jure discrimination when it was impossible to verify PPMs of imports.

After PreussenElektra, the EU has introduced the RED and has begun working to create a common energy market. Recently the principles of PreussenElektra were put to test again before the CJEU. Essent presented the authorities with foreign guarantees of origin (GOs) and asked to get them recognized as Belgian RECs. GOs and RECs are both certificates issued for electricity generated from renewable sources. On the one hand, the function of the GOs is simply to prove to customers that the electricity supplied is sustainably generated from renewable sources. RECs, on the other hand, both prove the origin and entitle the holder to use it for filling a renewable energy quota set on national level. Essent, however, reasoned that the GOs are sufficient to prove that the electricity will possess the environmental attributes required for receiving Belgian RECs. Similarly, in

\footnotetext{
${ }^{53}$ PreussenElektra, supra note 4, paras. 78-80. For criticism, see BJøRNEBYE, supra note 28, at 108.

${ }^{54}$ Case C-213/96, Outokumpu Oy, 1998 E.C.R. I-1777.

${ }^{55} / d .$, para. 37.

${ }^{56} / d$., para. 38

${ }^{57}$ Id., paras. 39-41.
} 
Ålands Vindkraft, the energy producer on the Finnish islands claimed its right to receive Swedish RECs for power it had supplied to Sweden.

With regard to the proportionality review, it should be noted that Advocate General Bot, in his opinion in Essent Belgium, argued that it is now possible to verify the source of imported energy ${ }^{58}$; the argument that the CJEU relied on in PreussenElektra should therefore no longer be relevant. Although the proposal of establishing harmonized system of guarantees of origin failed, ${ }^{59}$ Article 15 (9) and (10) RED still provide that all Member States shall issue guarantees of origin for electricity produced from renewable sources and that these guarantees shall be mutually recognized. ${ }^{60}$ Admittedly, the directive clearly distinguishes between GOs and RECs. ${ }^{61}$ Yet, the GOs often provide the information necessary to conclude whether or not the electricity that was generated would comply with the requirements for RECs-or any other benefit for that matter. ${ }^{62}$

The CJEU noted that the reasoning in PreussenElektra was outdated..$^{63}$ Still, it did not agree with the Advocate General when it proclaimed in Ålands Vindkraft that the origin of electricity was still too difficult to verify on the European market. ${ }^{64}$ This left the impression that not much had changed with regards to legal argumentation from the time of PreussenElektra to Ålands Vindkraft. ${ }^{65}$ Interestingly, a few months later in Essent Belgium, the CJEU did not bring up that same argument. The de jure discriminatory law was still upheld in that case, but for other reasons discussed below.

Verification of the PPMs of electricity is in some sense a unique case. Namely, with regard to physically separable goods-for example, fuel-any certificate of sustainable PPMs can

\footnotetext{
${ }^{58}$ Essent Belgium, supra note 6, paras. 102-03 (opinion of Advocate General Bot).

59 See Proposal for a Directive of the European Parliament and of the Council on the promotion of the use of energy from renewable sources, COM 2008(19) final. For a discussion on the weaknesses of the proposal see Johnston et al., supra note 50 .

$60 \mathrm{It}$ is not compulsory to issue these guarantees of origin for heating and cooling produced from renewable sources. Those forms of energy are, however, not frequently subject to international trade due to difficulties of transfer.

${ }^{61}$ RED, supra note 5 , recital 52.

${ }^{62}$ See also Johnston et al., supra note 50, 136.

63 Ålands Vindkraft, supra note 7, paras. 84-86.

${ }^{64}$ Id., paras. 87-88.

${ }^{65}$ Penttinen, supra note 32,11 \& 20.
} 
accompany the good in transactions and can be linked through identification numbers. In contrast, no unit of electricity generated to the network can be identified with any specific GO or REC. GOs will always follow the electricity contract unless sold on a power exchange where the $\mathrm{GO}$ becomes part of a certificate over a resource mix sold on the exchange. Furthermore, systems with RECs commonly allow them to be traded separately from the electricity. This creates a complex market wherein states will need to be able to verify that there is no double-counting before they can award their own RECs or any other benefit.

In conclusion, it should be possible to implement different treatment when sustainability cannot be verified. Yet, even if verification might be somewhat more complicated for imports, it would normally not justify de jure discrimination. The only exception would be when verification is not reasonably possible for any imports. These cases have been very rare. EU case law does imply that the PPMs of electricity could fall into that category, although the strength of the argument appears to be diminishing.

\section{H. Free-Riding, Leakage and System Stability}

\section{Renewable Portfolio Standards and Threat to System Stability}

A potential economic consequence of non-discriminatory support schemes is that producers of energy from renewable sources may start to search for the most beneficial national support schemes and only offer their clean energy to those countries. ${ }^{66}$ This would create a competitive market for various forms of support schemes, which as such would not be problematic. After all, free competition is at the core of free trade regimes. Yet, the risk of free riding may be a reason for concern. Some states would invest heavily in promoting renewables and companies of other states would reap the benefits, even if their home-states would barely contribute at all. This pattern could endanger system stability.

The CJEU has relied on system stability as a valid ground of justification in free movement law with regards to past cases of de jure discrimination. Most notably in cases on the free movement of patients the CJEU ruled that restrictions for out-of-state persons are upheld when it comes to non-emergency hospital care. The justification for such conclusion lay in the fact that building up the national healthcare system requires extensive planning and

\footnotetext{
66 Proposal for a Directive of the European Parliament and of the Council on the promotion of electricity from renewable energy sources in the internal electricity market, $\operatorname{COM}(2000) 279$ final, 6; Angus Johnston et al., supra note 50, 137; JOHNSTON \& BLOCK, supra note 50, at 350.
} 
any abnormal influx of patients would likely threaten the financial stability of the system. ${ }^{67}$ The real risk of significant influx of patients is, of course, questionable.

PreussenElektra concerned a German FIT and, even if the system stability argument could have been applicable, the CJEU did not address it. Interestingly, the argument appeared instead to emerge in Allands Vindkraft and Essent Belgium, which related to the RPS of each respective country. In Essent Belgium the court's focus appeared to shift away from verification difficulties. Thus, perhaps the decisive argument for de jure discrimination presented in the judgments of 2014 was that Member States would otherwise not have control of the effects and costs of the programs. ${ }^{68}$ These concerns were already reflected in the preamble of the RED. ${ }^{69}$ The court in Essent Belgium emphasized that the proper functioning of the national support scheme and the demand for RECs had to be guaranteed..$^{70}$ In sum, the court seemed to imply that without de jure discrimination the burden on some states would become too high; other states might free ride, and the stability of the renewable support systems would be endangered. ${ }^{71}$

Leakage has been a problem commonly debated in relation to cap-and-trade (emissions trading) systems. ${ }^{72}$ How do benefits then leak under a RPS scheme? Similarly to any ETS, a RPS may in a worst case scenario result in no new incentives for clean PPMs. Granting RECS

\footnotetext{
${ }^{67}$ Case C-158/96, Kohll, Raymond Kohll v Union des caisses de maladie, 1998 E.C.R. I-1931, para. 41; Case C368/98, Abdon Vanbraekel and Others v. Alliance nationale des mutualités chrétiennes (ANMC), 2001 E.C.R. I5363, para. 47; Case C-157/99, B.S.M. Geraets-Smits v. Stichting Ziekenfonds VGZ and H.T.M. Peerbooms v. Stichting CZ Groep Zorgverzekeringen, 2001 E.C.R. I-5473, paras. 72-81; Case C-385/99, V.G. Müller-Fauré v. Onderlinge Waarborgmaatschappij OZ Zorgverzekeringen UA and E.E.M. van Riet v. Onderlinge Waarborgmaatschappij ZAO Zorgverzekeringen, 2003 E.C.R. I-4509, paras. 77-82; Case C-56/01, Patricia Inizan v. Caisse primaire d'assurance maladie des Hauts-de-Seine 2003 E.C.R. I-12403, para. 56; Case C-372/04, The Queen, on the application of Yvonne Watts v. Bedford Primary Care Trust and Secretary of State for Health, 2006 E.C.R. I4325, paras. 112-13. Compare with Case C-204/90, Hanns-Martin Bachmann v. Belgian State, 1992 E.C.R. I-249, paras. 21-28. In this latter case, the need for cohesion of the tax system justified a restriction on the free movement of workers. See also Max S. Jansson, EU's kompetens i fråga om hälsovårdstjänster, 3-4 NORDISK SOCIALRÄTTSLIG TIDSKRIFT 95 (2011).

${ }_{68}$ Ålands Vindkraft, supra note 7, paras. 99, 103; Essent Belgium, supra note 6, para. 102.

${ }^{69}$ RED, supra note 5, recital 25.

${ }^{70}$ Essent Belgium, supra note 6, paras. 101, 109.

${ }^{71}$ Already hinting toward this, see Steinbach \& Brückmann, supra note 20, at 14.

72 The ETS has been set up by Directive 2003/87/EC of the European Parliament and of the Council of 13 October 2003 establishing a scheme for greenhouse gas emission allowance trading within the Community and amending Council Directive 96/61/EC, O.J. L 275, 32 (Oct. 25, 2003).
} 
to out-of-state renewable energy projects would allow the quantity of RECS to increase exponentially. The influx of RECs or requests for RECs will especially originate from states that do not have any RPS system or very low quotas. From an environmental perspective, this may be problematic because even if states would not be justified in prioritizing their own environment, the non-discriminatory RPS would invite the states with no or low quotas to get RECs for their renewable energy. The quota of the importing state would then be saturated without there having been any increase in renewable energy globally. The problem could also be described as a form of reshuffling.

The increase in RECs would drive prices down and retailers could fulfill their quota easily by buying dirty energy and very cheap RECs. The environmental benefits of the RPS would be more or less nullified. This explains also why system stability would not be a prohibited pure economic concern, but more of a structural question related to environmental protection. ${ }^{73}$ Through discrimination, the state may avoid free riding and secure efficiency.

\section{System Stability and Government Spending}

The 2014 CJEU judgments in Ålands Vindkraft and Essent Belgium related to RPS-models. It has been assumed that the reasoning found within these two cases would apply equally to other forms of schemes such as FITs. ${ }^{74}$ This presumption requires a bit more elaboration.

RPS schemes rely on quota obligations and do not involve direct government spending. In contrast, FIT and grant programs rely upon public authorities to offer direct financial support. An EU Member State might be concerned that too many applications come in and threaten financial stability. Still, as an alternative to de jure discrimination, the state could opt to limit the number of annually accepted applications. Capping FITs or subsidies will, however, create some uncertainty, as the producers cannot know when funds will run out. In addition, states that implement programs to promote renewables may see their investment leak to other states. This will, in turn, discourage other states from implementing such programs to protect the environment. ${ }^{75}$

In Ålands Vindkraft and Essent Belgium, the CJEU added that, even for a RPS, the elimination of the in-state requirement would risk resulting in reduced investor

\footnotetext{
73 In the context of free movement of patients and hospital care, see also Vassilis Hatzopoulos, Recent Developments of the Case Law of the ECJ in the Filed of Services, 37 Common MKT. L. REV. 43, 79 (2000).

${ }^{74}$ Szydło, supra note 32, at 497.

${ }^{75}$ Engel, supra note 8, at 270.
} 
confidence. ${ }^{76}$ Together with the argument of financial stability, the risk of reduced investor confidence could thus justify de jure discrimination. The lines of reasoning in the recent cases thus provide for new grounds of justification for de jure discriminatory FITs and similar programs.

\section{Interconnections, Delivery and Consumption Criteria}

The CJEU found de jure discrimination to be justifiable in Ålands Vindkraft and Essent Belgium. Of the various justifications, system stability appeared the most solid. In this process, the court came to reject the alternative of eliminating the in-state requirement completely. It is, however, unfortunate that the court did not discuss any other alternatives. ${ }^{77}$

In accordance with the proportionality principle, states should not adopt a discriminatory measure if there is an alternative that is less discriminatory that would still guarantee the same level of protection. In the U.S., a debate has emerged as to whether not in-state requirements are disproportionate. The alternative would be requirements of grid interconnection with, delivery to, or even consumption in the state where the support, often in the form of RECs, is granted. ${ }^{78}$ Electricity generated out-of-state would receive $\mathrm{RECs}$ if the interconnection, delivery or consumption requirement is met.

The U.S. debate offers two important lessons for the EU doctrine: First and foremost, the CJEU statements on the necessity of national control of effects and costs of the renewable energy schemes could be understood as recognition of the same risks of reshuffling or RECinflation that have been discussed by U.S. scholars. Secondly, consumption and delivery requirements as alternatives to de jure discrimination could also have been relevant under EU free movement law. It is unfortunate that the CJEU never addressed this aspect in Essent Belgium and Ålands Vindkraft.

\footnotetext{
${ }^{76}$ Ålands Vindkraft, supra note 7, paras. 99, 103; Essent Belgium, supra note 6, para. 102.

${ }_{77}$ Szydło, supra note 32, at 505-06.

${ }^{78}$ Endrud, supra note 8, 271-73; Jacobi, supra note 8, at 1128-134; Elefant \& Holt, supra note 8, 4 \& 12; Anne Havemann, supra note 46, at 884; Steven Ferrey, Renewable Orphans: Adopting Legal Renewable Standards at the State Level, 19 ELECTRICITY J. L. 52, 59-60 (2006); Stiles, supra note 8, at 65. Compare however with Daniel K. Lee \& Timothy P. Duane, Putting the Dormant Commerce Clause Back to Sleep: Adapting the Doctrine to Support State Renewable Portfolio Standards, 43 ENVIR. L. 295, 333-34 (2013). Such requirements have already been implemented in state laws. See Joel H. Mack et al., All RECS are Local: How In-State Generation Requirements Adversely Affect Development of a Robust REC Market, 24 ELECTRICITY J. L. 8, 11-13 (2011).
} 
At least in the case of Allands Vindkraft, the electricity producer actually delivered the electricity to Sweden. This was pointed out by Advocate General Bot, who also noted that, in general, the limited interconnections between national grids in Europe would hinder any massive influx of REC-applications from other states. ${ }^{79}$ The CJEU chose not to address this point, consequently leaving the impression that even a delivery requirement would not guarantee the same level of environmental protection. Ironically, had that view been upheld, it would have meant that restrictions to the free movement of electricity would be easier to justify when interconnections and cross-border trade would increase. ${ }^{80}$

A reason for not giving preference to the alternative of delivery or consumption requirements lies in the complexity of such models. In other words, it could be technically difficult and/or financially unreasonable to verify that electricity has actually been delivered from a green power plant and even more difficult to verify that it was never reexported.

\section{J. Conclusions}

While states in the U.S. have quickly repealed the requirement of in-state production from their RPSs when challenged in court, EU Member States have been granted by the legislature the right to implement such de jure discrimination. This right has once again been confirmed by the CJEU in Ålands Vindkraft and Essent Belgium.

Generally, the rulings in Ålands Vindkraft and Essent Belgium have received a positive response. Yet, while some have applauded the legal reasoning in those cases, ${ }^{81}$ others have read the decisions more in light of political reality. ${ }^{82}$ Neither of these approaches is incorrect. Surely, the CJEU was affected by fears linked to the uncertainty of the faith of renewable support schemes that would have followed from striking down the in-state requirements. Relying on system stability, the court may still have found a convincing legal argument to support its reasoning. What is more, this argument had been used before in cases relating to free movement of healthcare services. If this reading is correct, the CJEU

\footnotetext{
79 Ålands Vindkraft, supra note 7, para. 98 (opinion of AG Bot). His suggestion to compensate for the REC-inflation with higher quotas would not work though in cases where the influx of RECs is extremely high.

80 On free movement of patients/healthcare services, see also Mark Flear, Case C-385/99 V.G. Müller-Fauré v. Onderlinge Waarborgmaatschappij O.Z. Zorgverzekeringen U.A. and E.E.M. van Riet v. Onderlinge Waarborgmaatschappij Z.A.O. Zorgverzekeringen, 41 COMMON MKT. L. REV. 209, 223 (2004).

${ }^{81}$ Bjørnebye, supra note 24 , at 9.

${ }^{82}$ Penttinen, supra note 32, at 22; Szydło, supra note 32, at 507.
} 
may have been moving away from the argument of verification difficulties that it endorsed almost two decades earlier in PreussenElektra, when the energy sector looked rather different.

In future cases, the CJEU may be asked to elaborate why consumption or delivery requirements could not serve as less discriminatory alternatives that guarantee more or less the same level of environmental protection as a requirement of in-state production. From the perspective of comparative law, the rulings in Alands Vindkraft and Essent Belgium illustrated that the CJEU was either untouched or unaware of the American debate on identical questions. This is, perhaps, not ideal in a globalized world, especially considering the similarities between EU free movement law and the U.S. Dormant Commerce Clause.

On a final note, the CJEU has, in many sectors, been the driving force of further integration. With regard to energy trade the case law has, however, now for the time being cemented the fragmentation of the EU market. It will be up to the legislature to decide whether to introduce common EU level support schemes. ${ }^{83} \mathrm{~A}$ common system would seem indispensable for fulfilling the ambitions of a fully-integrated internal European energy market.

\footnotetext{
83 Szydło, supra note 32, at 507-09; Miquel Munoz, Volker Oschmann \& David Tabara, Harmonization of Renewable Electricity Feed-In Laws in the European Union, 35 ENERGY PoL'Y 3104 (2007); Jaap Jansen \& Martine Uyterlinde, A Fragmented Market on the Way to Harmonisation? EU Policy-Making on the Renewable Energy Promotion, 8 ENERGY FOR SUSTAINABLE DEVELOPMENT 93 (2004).
} 